\title{
Nano-scale liposomal container with a «signal system» for substances delivering in living cells
}

\author{
S. L. Yefimova, A. S. Lebed, G. Ya. Guralchuk, A. V. Sorokin, \\ I. Yu. Kurilchenko', N. S. Kavok, Yu. V. Malyukin \\ Institute for Scintillation Materials NAS of Ukraine \\ 60, Lenin Ave., Kharkiv, Ukraine, 61001 \\ ${ }^{1}$ Slovyans'k State Pedagogical University \\ 19, Batyuka Str., Slovyans'k, Ukraine, 84116 \\ ephimova@isma.kharkov.ua
}

\begin{abstract}
Aim. The aim of this research is to study the possibility to supply the nano-scale liposomal "container», used for the targeted substance delivery inside the living cells, with a «signal system» to trace the liposome fate in real time. Methods. For this purpose, the methods of fluorescence microscopy, fluorescence spectroscopy and microspectroscopy have been used. Results. The cellular uptake of hydrophobic fluorescent probes DiO and DiI, preloaded in phosphatidylcholine (PC) liposomes, in real time has been studied using fluorescence resonance energy transfer (FRET) from the donor probe DiO to the acceptor one DiI. It has been revealed that after 3 hours incubation of hepatocytes with FRET liposomes, the FRET signal almost disappears, whereas DiO fluorescence becomes very intensive. Conclusions. The loss of FRET signal could be used as a «signal system» to monitor the cell-liposome fusion and delivery of any active compounds to cells.

Key words: liposomes, fluorescent probes, cells, fluorescence resonance energy transfer.
\end{abstract}

Introduction. Among the widely studied drug delivery vehicles, liposomal ones are of special interest due to their attractive properties [1-3]. Liposomes consist of aqueous core entrapped by one or more bilayers of natural and/or synthetic lipids that allows solubilization of both water-soluble and lipo-soluble compounds. Liposomes, composed of natural lipids, are biodegradable, biologically inert, weakly immunogenic and possess limited intrinsic toxicity [4]. Moreover, liposomes afford a unique opportunity to deliver the drugs into cells by fusion or endocytosis mechanism, i. e. by the atraumatic for cells way [3, 4]. Liposomes can provide targeted delivery of active compounds into sites of

(C) Institute of Molecular Biology and Genetics NAS of Ukraine, 2011 action in living cells that is very attractive for medical, biological and pharmaceutical applications [3, 4]. However, a lot of questions are still open. Fluorescent imaging has become an invaluable tool in biomedical researches that can trace the liposome fate in a living cell and help answer many questions including the pathway for cellular internalization of liposomes and incorporated active compounds. For this purpose, a liposome should be supplied with special «signal system» that traces the liposome fate and visualizes the active compound release. Fluorescent probes can play this role [4].

In this study, we investigate in real time the cellular uptake of hydrophobic fluorescent probes preloaded in phosphatidylcholine (PC) liposomes. For this purpose 


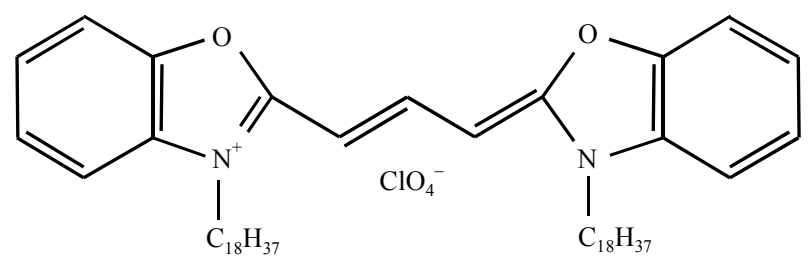

$a$

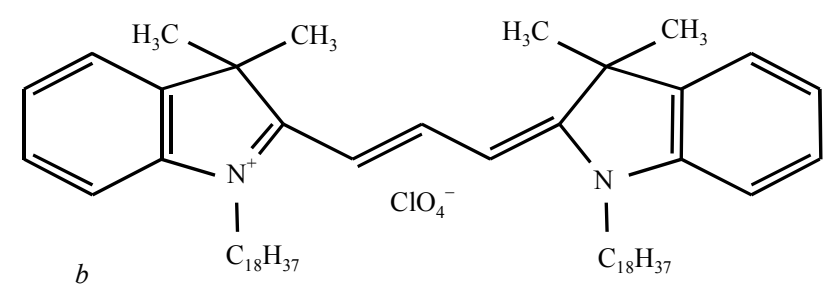

Fig. 1. Structural formulas of fluorescence probes: $a-3,3$ '-dioctadecyloxacarbocyanine perchlorate (DiO); $b-1,1^{\prime}$-dioctadecyl-3,3, 3',3'-tetramethylindocarbocyanine perchlorate (DiI)

we used such a fundamental phenomenon in fluorescence spectroscopy as fluorescence resonance energy transfer (FRET). FRET is a transfer of electronic excitation energy from one molecule (donor) to other molecule (acceptor) without intermediate photon emission through long-range dipole-dipole interactions [5]. Since FRET efficiency depends critically on the separation between the donor and acceptor molecules, it is widely used to study a variety of biological processes associated with the intermolecular distance changing [5]. FRET is one of the powerful biophysical methods to characterize the interactions between molecules located at small distances (up to $10 \mathrm{~nm}$ ) [5]. In molecular biology FRET is very often used to analyze the spatial structures of macromolecules (as protein folding, DNA packaging, etc.), supramolecular structures (as ligand receptor interactions, etc.), and the interactions among molecular membrane components [5]. In our research, hydrophobic dyes 3,3'-dioctadecyloxacarbocyanine perchlorate (DiO) and 1,1'-dioctadecyl-3,3,3',3'-tetramethylindocarbocyanine perchlorate (Dil) were used as energy donor and acceptor, respectively (Fig. 1). The pair of DiO and DiI dyes is used in various FRETbased applications $[4,6,7]$. In our case, the dyes were pre-loaded in lipid bilayers of PC liposomes that ensured the required distance between the donor $\mathrm{DiO}$ and the acceptor DiI to realize FRET. The release of the dyes from liposomes causes a loss of the FRET effect due to an increase of the donor-acceptor distance [5].

Materials and methods. Chemicals. Fluorescent probe $\mathrm{DiO}$ was synthesized in the Institute for Scintillation Materials NAS of Ukraine by Dr. I. Borovoy. The purity of the dye was controlled by thin layer chromatography. Dye DiI and L- $\alpha$-phosphatidylcholine from egg yolk were purchased from «Sigma-Aldrich» (USA) and used without purification. Chloroform («Sigma-Aldrich») used to prepare lipid and dye stock solutions was a spectroscopic grade product. Dimethyl formamide (DMF, «Sigma-Aldrich») was also of spectroscopic grade.

Preparation of lipid vesicles with $\mathrm{DiO}$ and DiI probes. Unilamellar PC lipid vesicles containing DiO and DiI dyes were prepared by the extrusion method [8]. Briefly, appropriate amount of PC $(50 \mathrm{mg} / \mathrm{ml})$ and dyes $\left(10^{-3} \mathrm{M}\right)$ stock solutions in chloroform were mixed in a flask and dried until complete chloroform evaporation. The thin lipid-dyes film was then hydrated with $2 \mathrm{ml}$ of Eagle's medium $+10 \%$ fetal calf serum $(\mathrm{pH}$ 7.4). The obtained lipid-dyes suspension was finally extruded through $200 \mathrm{~nm}$ pore size polycarbonate filter. The concentrations of the DiO and Dil dyes in liposomal suspension were $2 \cdot 10^{-5} \mathrm{M}$. In order to ensure that the lipid mixture was in equilibrium state, the prepared vesicles rested overnight at $22{ }^{\circ} \mathrm{C}$ and the measurements took place on the following day.

Cell labeling procedure. The experiments were carried out using freshly isolated hepatocytes of threemonth Vistar-rats males. Hepatocytes were derived from rat liver by the non-enzymatic method [9] with following washing-out with Eagle's medium with $10 \%$ fetal calf serum. The cells pellet $\left(50 \mu 10^{7}\right.$ cells $\left./ \mathrm{ml}\right)$ were incubated with liposomal suspension $(50 \mu \mathrm{l})$ in $1 \mathrm{ml}$ of Eagle's medium with $10 \%$ fetal calf serum at $37^{\circ} \mathrm{C}$ for required time intervals $(1,2,3$ and $20 \mathrm{~h})$. Afterwards non-bound liposomes were removed by centrifugation at $500 \mathrm{~g}$ and washing-out by adding HBSS (HEPES buffered saline solution) buffer ( $\mathrm{pH}$ 7.4) with $0,1 \%$ BSA.

Cell imaging, microspectroscopy and spectrosco$p y$. Cell imaging was performed using inverted fluorescent microscope Olympus IX71 with digital camera Olympus C-5060. BP 460-490 and BP 510-550 filters were used to excite $\mathrm{DiO}$ and DiI, respectively. To study 


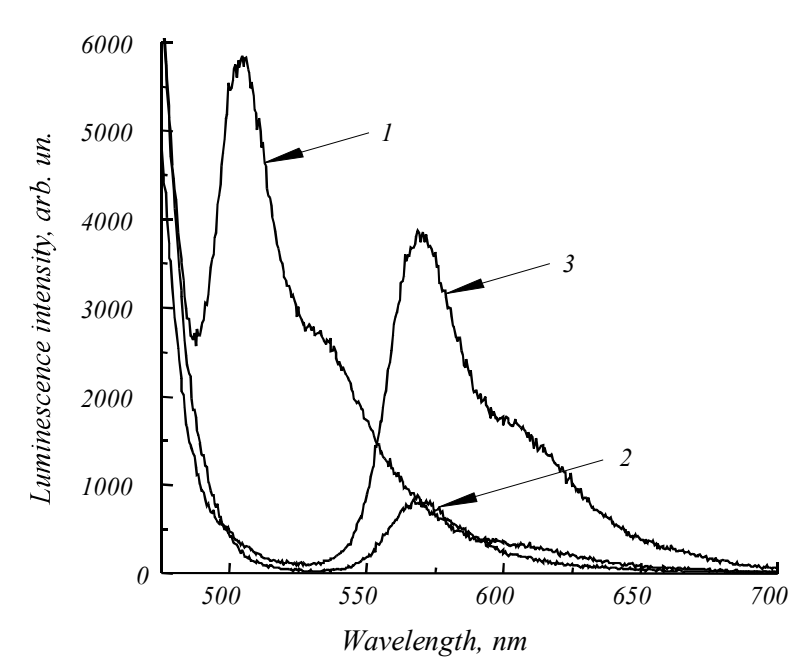

Fig. 2. Fluorescence spectra of liposomal suspensions: 1-DiO-loaded liposomes; 2 -DiI-loaded liposomes; 3 -FRET liposomes. The fluorescence was excited at $460 \mathrm{~nm}$

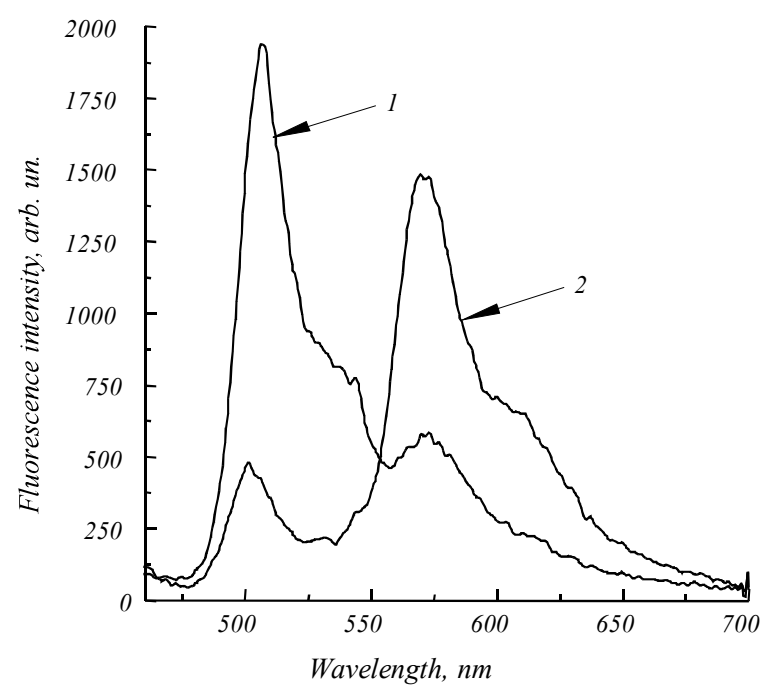

Fig. 3. Fluorescence spectra of DiO and DiI probes in different media: 1 - DMF; 2 - liposomes

FRET in cells, BP 460-490 filter was used. Microspectroscopy at the area of interest was carried out using spectral detector USB 4000 (Ocean Optics) connected with Olympus IX71. Fluorescence spectra of the liposomal suspensions with fluorescent probes were obtained using a spectrofluorimeter on the base of two grating monochromators MDR-23 and a xenon lamp. One of the monochromator was used to select a required wavelength (full width at half maximum, FWHM $=0,5 \mathrm{~nm}$ ), the other one was used for the fluorescence collection.
Results and discussion. The fluorescence of the lipid suspension with the dyes was excited at 460 and $490 \mathrm{~nm}$ to pattern the excitation in a fluorescent microscope (BP 460-490 filter). Forced concentration of hydrophobic fluorescent probes in liposome lipid bilayers ensures the required distance between the donor DiO and acceptor DiI to observe FRET (Fig. 2, curve $3)$. The FRET ratio calculated as $I_{R} /\left(I_{G}+I_{R}\right)$, where $I_{R}$ and $I_{G}$ are fluorescence intensities of DiI at $570 \mathrm{~nm}$ and $\mathrm{DiO}$ at $504 \mathrm{~nm}$, respectively, was 0.98 . To estimate the contribution of the donor emission in the FRET spectrum and the acceptor direct excitation at $460 \mathrm{~nm}$, fluorescence spectra of liposomes with DiO only and liposomes with DiI only were measured (Fig. 2, curves 1 , 2). As one can see from Fig. 2, the contribution of DiO to DiI emission can not be taken into consideration, because the FRET DiO fluorescence is absent (Fig. 2, curve 3). The direct excitation of DiI at $460 \mathrm{~nm}$ (Fig. 2, curve 2) is small as compared with the total DiI signal of FRET liposomes (Fig. 2, curve 3). At $490 \mathrm{~nm}$ excitation, DiI emission signal is stronger, but the total DiI signal of FRET liposomes is also stronger. So, the ratio DiI alone/DiI in FRET liposomes remains the same.

When in a solution there are no «containers» that ensures the required distance between the donor and acceptor molecules, the energy transfer disappears (Fig. 3, curve 1). Fig. 3 represents fluorescence spectra of DiO and DiI dyes in DMF and liposome suspension. As one can see, in DMF, where both DiO and DiI are soluble, at the same dyes concentration, FRET is almost not observed. In such a solution, the FRET ratio $I_{R} /\left(I_{G}+I_{R}\right)$ is 0.23 vs 0.98 observed in liposome suspension.

Therefore, we can suppose that the damage of liposomes as a result of the liposome-cell interaction will cause the release of the dyes from liposomes and loss of the FRET effect due to an increase of the donoracceptor distance [5]. So, the loss of FRET signal could be used as a «signal system» to monitor the delivery of any active compounds to cells.

To monitor the dynamics of the $\mathrm{DiO}$ and DiI release from the PC liposomes, the liposomes were mixed with the cell suspension as described above and incubated during different time periods. During the experiment, we control both $\mathrm{DiO}$ and DiI fluorescence changes depending on incubation time. Fig. 4, see inset, represents 

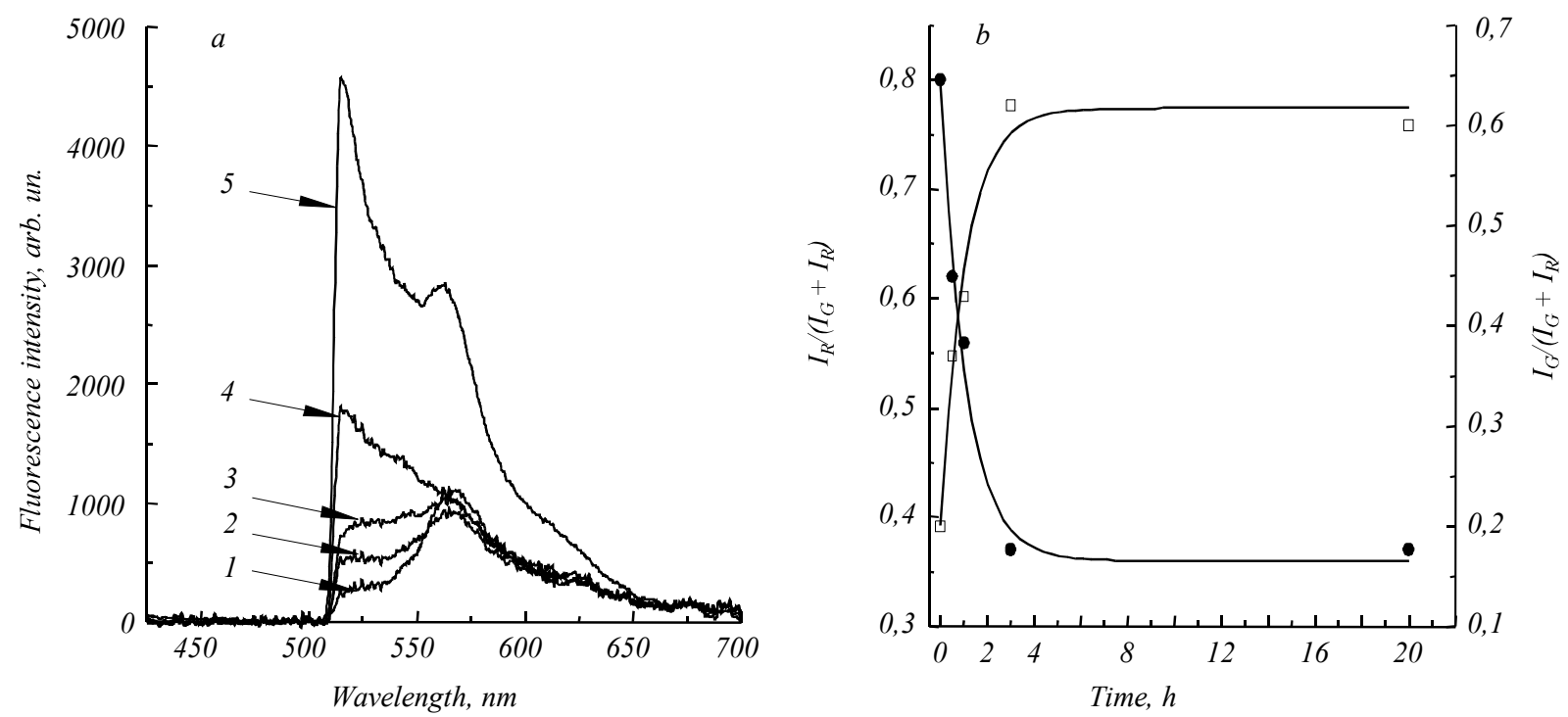

Fig. 5. Fluorescence spectra recorded from hepatocytes incubated with FRET liposomes during different time periods ( $a$ : 1 - FRET liposomes without cells; $2-0 \mathrm{~min} ; 3-1 \mathrm{~h} ; 4-3 \mathrm{~h} ; 5-20 \mathrm{~h}$; excitation with BP $460-490$ filter $)$; and changes in time of $\mathrm{DiO}, I_{G} /\left(I_{G}+I_{R}\right)$, and DiI, $I_{R} /\left(I_{G}+I_{R}\right)$, relative fluorescence signals $(b)$

fluorescent images of the cells taken over different time periods. Fluorescence spectra recorded from the fluorescent cell areas using a spectral detector connected with a fluorescent microscope are shown in Fig. 5, a. Fig. 4, $a$ (see inset) shows that immediately after the cells-liposome mixing and further washing out, the cell fluorescent image is represented by the cell autofluorescence. One can also observe FRET liposomes bound to the cell membrane. Fluorescent spectrum recorded from this cell is presented in Fig. 5, a, curve 2. This spectrum is almost identical to the one recorded from the FRET liposomes (Fig. 5, a, curve 1, FRET ratio $I_{R} /\left(I_{G}+I_{R}\right)$ is 0.78$)$ with a slight contribution of the autofluorescence peak at $520 \mathrm{~nm}$. After $1 \mathrm{~h}$ incubation, a redistribution of $\mathrm{DiO}$ and DiI peaks in the fluorescence spectrum can be observed (Fig. 5, $a$, curve 3). The DiO fluorescence ratio $I_{G}\left(I_{G}+I_{R}\right)$ increases from 0.2 to 0.43 , while the FRET ratio $I_{R} /\left(I_{G}+I_{R}\right)$ decreases from 0.78 to 0.56 (Fig. 5, $b$ ). Fig. 4, images $a-e$ (see inset), represents the changes in $\mathrm{DiO}$ fluorescence intensity depending on the cell-liposome incubation period. As we can see from Fig. 5, $a, b$, after 3 hours incubation, the $\mathrm{DiO} / \mathrm{DiI}$ fluorescence signal redistribution is finished. The $\mathrm{DiO}$ fluorescence signal becomes more intensive than the DiI one, $I_{G} /\left(I_{G}+I_{R}\right)$ and $I_{R} /\left(I_{G}+I_{R}\right)$ ratios are 0.62 and 0.37 , respectively (Fig. 5, $a, b$ ). Further increase in incubation time does not cause the
$\mathrm{DiO} / \mathrm{DiI}$ ratio increase, and even during $20 \mathrm{~h}$ incubation the ratio is just the same (Fig. 5, b). However, the intensity of $\mathrm{DiO}$ and DiI fluorescence increases gradually in time (Fig. 4, see inset, and Fig. 5, a).

Thus, the decrease of Dil fluorescence signal in time and increase of $\mathrm{DiO}$ fluorescence indicate a release of the probes from the liposomes as the result of the cell-liposome interaction where the FRET effect is significantly diminished. On the other hand, such a result could be observed, if the dyes $\mathrm{DiO}$ and DiI escape from the liposomes in time due to liposome instability etc. Literature analysis $[1,6,7,10]$ and our investigations revealed that in the analyzed time period $(20 \mathrm{~h}) \mathrm{PC}$ liposomes are stable and the hydrophobic probe leakage is not observed. Moreover, our studying the efficiency of hydrophobic dye binding to the cell membrane model system (surfactant micelles) shows that $\mathrm{DiO}$ and DiI are characterized by high binding ability [11]. So, we can conclude that the decrease in the FRET efficiency in time is caused by the DiO and DiI internalization as a result of cell-liposome binding that does not ensures the required for FRET distance between the donor and acceptor. Fig. 4 , images $e$ and $f$, show that after $20 \mathrm{~h}$ cells-liposomes incubation, both dyes are observed in cells in large amount, the intensities of green and red (excitation with a BP 510-550 filter) signals are very strong. 
It is known that liposomes can penetrate into cells by different mechanisms: 1) fusion of liposomal vesicle membrane and cell membrane; 2) endocytosis mechanism; 3) liposome adsorption on a cell membrane with a subsequent facilitated diffusion of the active component into the cell; 4) active liposome transport [12]. At this stage of our research we can not specify the way of liposome uptake. In [7] the authors suggest a membrane-mediated pathway for cellular uptake of hydrophobic molecules preloaded into the core of polymeric micelles. It was shown that hydrophobic molecules could be efficiently transferred to lipid bilayers (cell membrane) within minutes, where the lipid bilayers served as a sink to accommodate these molecules before internalization [7]. After $2 \mathrm{~h}$ incubation of HeLa cells with polymer micelles containing DiI the dye could be observed inside the cells [7].

In our research, in $3 \mathrm{~h}$ incubation, the $\mathrm{DiO} / \mathrm{DiI}$ ratio reaches its maxima, so we can conclude that the similar pathway of the dyes internalization could be possible in our case too. This assumption is also supported by the following fact. After $20 \mathrm{~h}$ incubation, intensities of green and red signals are very strong. So, both dyes are located in cells, but we do not observe FRET signal recovering that should be observed due to the dyeto-dye distance shortening. That means that the dyes could be located not only in cell membrane, but also inside the cells.

Conclusions. The cellular uptake of hydrophobic fluorescent probes, preloaded in PC liposomes, has been studied in real time using fluorescence resonance energy transfer from the donor probe $\mathrm{DiO}$ to the acceptor one DiI. It was revealed that after 3 hours incubation of hepatocytes with FRET liposomes, the FRET signal almost disappeared, whereas $\mathrm{DiO}$ fluorescence became very intensive. $I_{R} /\left(I_{G}+I_{R}\right)$ and $I_{G} /\left(I_{G}+I_{R}\right)$ ratios were 0.37 and 0.62 , respectively. The loss of FRET signal could be used as a «signal system» to monitor the cell-liposome fusion and delivery of any active compounds to cells. A membrane-mediated pathway for cellular uptake of $\mathrm{DiO}$ and DiI dyes preloaded into PC liposomes is supposed. However, this assumption should be verified that will be the subject of our further research.
С. Л. Сфімова, А. С. Лебедь, Г. Я. Гуральчук, А. В. Сорокін, І. Ю. Курильченко, Н. С. Кавок, Ю. В. Малюкін

Нанорозмірний ліпосомний контейнер із «сигнальною системою» для спрямованої доставки речовин у живі клітини

Резюме

Мета. Встановити можливість оснащення ліпосомних «контейнерів», які використовують для спрямованої доставки речовин уживі клітини, «сигнальною системою» для відстеження взаємодії ліпосом з клітинами у часі. Методи. Використано методи флуоресцентної мікроскопї̈, флуоресцентної спектроскопії і мікроспектроскопії. Результати. Із застосуванням ефекту безвипромінювального перенесення енергї електронного збудження (БПЕ) від зонда-донора DiO до зонда-акцептора DiI, інкорпорованих у ліпідні бімари фосфатидилхоліну (РС) ліпосом, вивчено прочес входження гідрофобних флуоресцентних зондів у клітину. Визначено, що після 3 год інкубаиії клітин гепатоцитів з ліпосомами, у яких спостерігається БПЕ між парою зондів, сигнал БПЕ практично зникає, у той час як флуоресценція донора DiO стає дуже інтенсивною. Висновки. Ефект втрати сигналу БПЕ можна використовувати як «сигнальну систему» для моніторингу взаємодї ліпосоми з клітиною та доставки активної речовини у клітину.

Ключові слова: ліпосоми, флуоресиентні зонди, клітини, безвипромінювальне перенесення енергіï.

С. Л. Ефимова, А. С. Лебедь, Г. Я. Гуральчук, А. В. Сорокин, И. Ю. Курильченко, Н. С. Кавок, Ю. В. Малюкин

Наноразмерный липосомный контейнер с «сигнальной системой» для направленной доставки веществ в живые клетки

Резюме

Цель. Установить возможность снабжения липосомных «контейнеров», используемых для направленной доставки веществ в живые клетки, «сигнальной системой» для отслеживания взаимодействия липосом с клетками во времени. Методы. В работе использованы методы флуоресиентной микроскопии, флуоресиентной спектроскопии и микроспектроскопии. Результаты. С применением безызлучательного переноса энергии электронного возбуждения (БПЭ) от зонда-донора DiO кзонду-акцептору DiI, инкорпорированных в липидные бислои фосфатидилхолина (РС) липосом, изучен прочесс вхождения гидрофобных флуоресиентных зондов в клетку. Обнаружено, что после 3 ч инкубации клеток гепатоцитов с липосомами, в которых наблюдается БПЭ между парой зондов, сигнал БПЭ практически исчезает, в то время как флуоресчениия донора DiO становится очень интенсивной. Выводы. Эффект потери сигнала БПЭ можно использовать в качестве «сигнальной системы» для мониторинга взаимодействия липосомы с клеткой и доставки активного вещества в клетку.

Ключевые слова: липосомы, флуоресиентные зонды, клетки, безызлучательный перенос энергии.

\section{REFERENCES}

1. Torchilin $V$., Weissig $V$. Liposomes. A practical approach series.-Oxford: Univ. press, 2003.-396 p. 
2. Kozubek A., Gubernator J., Przeworska E., Stasiuk M. Liposomal drug delivery, a novel approach: PLARosomes // Acta Biochim. Pol.-2000.-47, N 3.-P. 639-649.

3. Goyal P., Goyal K., Vijaya Kumar S. G., Singh A., Katare O. P., Mishra D. N. Liposomal drug delivery systems - clinical applications // Acta Pharm.-2005.-55, N 1.-P. 1-25.

4. Hauglang R. P. Handbook of fluorescent probes and research products.-New York: Molecular probes, 2002.-966 p.

5. Lakowicz J. R. Principles of fluorescence spectroscopy.-New York: Plenum press, 1999.-725 p.

6. Chen H., Kim S., He W., Wang H., Low P. S., Park K., Cheng $J$. $-X$. Fast release of lipophilic agents from circulating PEGPDLLA micelles revealed by in vivo Forster resonance energy transfer imaging // Langmuir.-2008.-24, N 10.-P. 52135217

7. Chen H., Kim S., Li L., Wang S., Park K., Cheng J.-X. Release of hydrophobic molecules from polymer micelles into cell membranes revealed by Forster resonance energy transfer imaging // Proc. Natl Acad. Sci. USA.-2008.-105, N 18.P. 6596-6601.
8. Mui B., Chow L., Hope M. J. Extrusion technique to generate liposomes of defined size // Meth. Enzymol.-2003.-367.P. 3-14.

9. Petrenko A., Sukach A. N., Roslyakov A. D. Isolation of rat hepatocytes by a nonenzymatic method: detoxifying and respiratory activity // Biokhimiia.-1991.-56, N 9.-P. 1647-1651.

10. Loura L. M. S., Fedorov A., Prieto M. Partition of membrane probe in a gel/fluid two-component lipid system: a fluorescence resonance energy transfer study // Biochim. Biophys. Acta.-2000.-1467, N 1.-P. 101-112.

11. Lebed'A. S., Yefimova S. L., Guralchuk G. Ya., Sorokin A. V., Borovoy I. A., Malyukin Yu. V. Effect of hydrophobicity of cationic carbocyanine dyes $\mathrm{DiOC}_{n}$ on their binding to anionic surfactant micelles // J. Appl. Spectrosc.-2010.-77, N 2.P. 183-188.

12. Kaplun A. P., Son L. B., Krasnopol'skii Yu. M., Shvets V. I. Liposomes and other nanoparticles as drug delivery systems // Vopr. Med. Khim.-1999.-45, N 1.-P. 3-12.

UDC 577.336:547.9+57.085.2 Received 13.07.10 

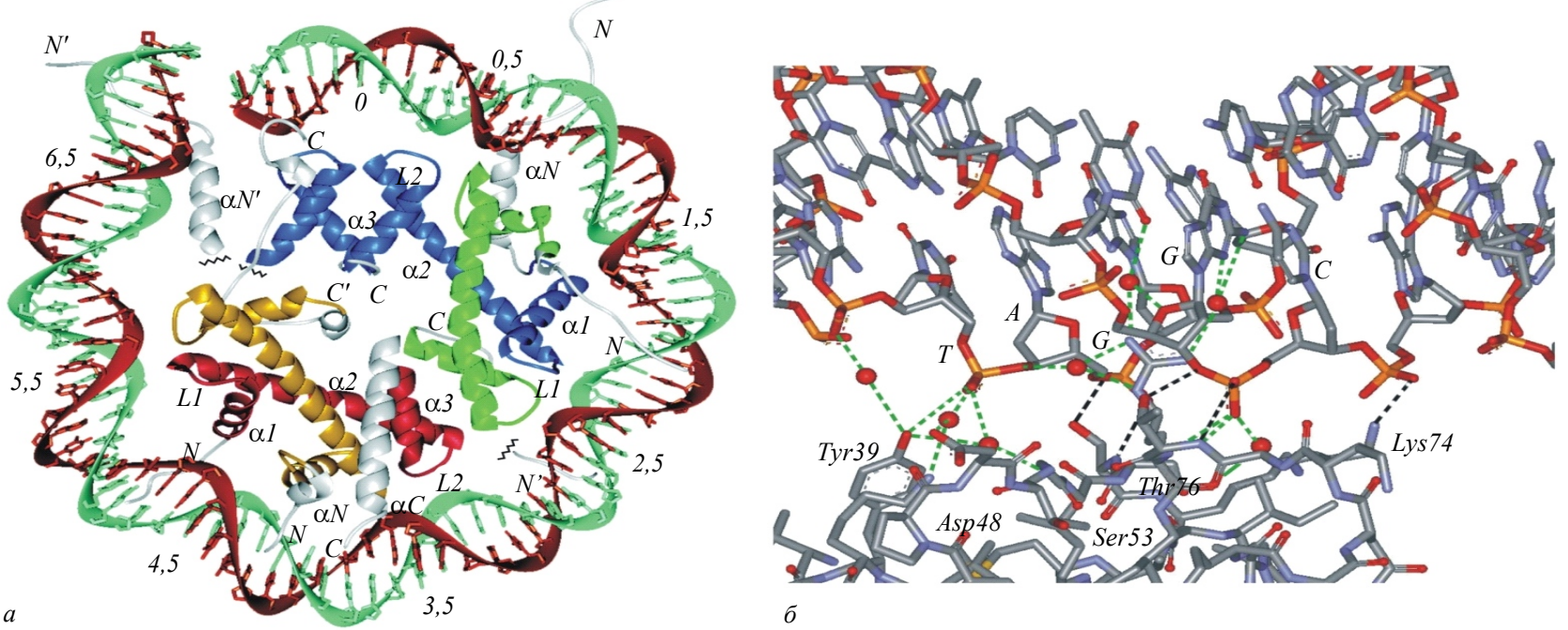

Рис. 6. Структура нуклеосомы (РDB-индекс $1 \mathrm{KX} 5$, сайты взаимодействия ДНК и гистонов обозначены цифрами) (a) и сайт связывания ДНК (сайт 5,5, выделены молекулы воды, занимающие мостиковые положения между донорно-акцепторными группами гистонового димера и сахарофосфатным остовом ДНК) (б)

Figures to article by S. L. Yefimova et al.
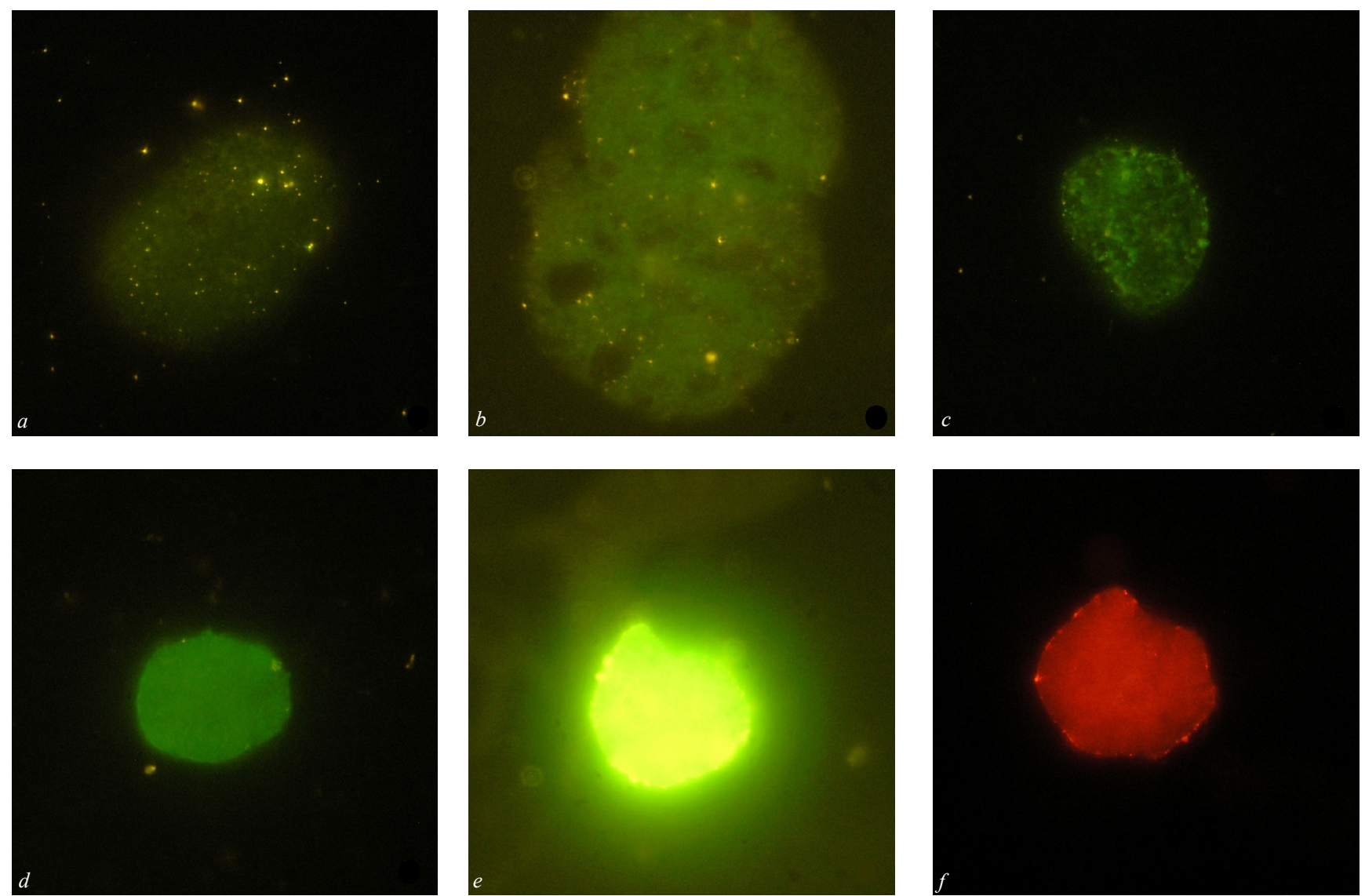

Fig. 4. Fluorescence images (original magnification $\times 100$ ) of rat hepatocytes incubated with FRET liposomes during different time periods: $a-0 \mathrm{~min} ; b-1 \mathrm{~h} ; c-2 \mathrm{~h} ; d-3 \mathrm{~h} ; e-20 \mathrm{~h}$ (excitation with BP $460-490$ filter); $f-20 \mathrm{~h}$ (excitation with BP $510-550$ filter) 